\title{
CONSUMER WELL-BEING: PERAN BRAND AUTHENTICITY, DAN DAMPAKNYA TERHADAP CONSUMER CITIZENSHIP BEHAVIOR
}

\author{
Nanang Gunawan ${ }^{1}$, Suharyono ${ }^{2}$, Sunarti $^{3}$ \\ Fakultas Ilmu Administrasi Universitas Brawijaya, Malang, Jawa Timur, Indonesia

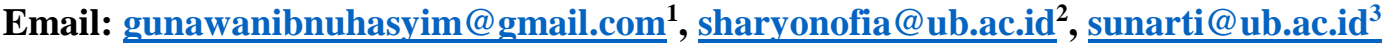

\begin{abstract}
This article aims to deepen knowledge about the importance of the concept of consumer well-being in marketing research, as well as to build propositions related to the potential for consumer well-being and its consequences for marketing outcomes. Through an in-depth study of the existing literature, it can be revealed that CWB is an important construct in marketing research and consumer behavior. $C W B$ measurement can be done by measuring consumer satisfaction which contributes to several positive states of consumers in the form of positive emotions, attachments, relationships, meaning, and achievement (PERMA). In addition, this article succeeded in building a proposition that brand authenticity can have a significant effect on CWB and marketing outcomes in the form of consumer citizenship behavior. The relationship between these variables is based on self-determination theory.
\end{abstract}

Keywords: Consumer Well-Being, Authenticity, Citizenship Behavior.

\begin{abstract}
ABSTRAK
Artikel ini bertujuan untuk memperdalam pengetahuan tentang pentingnya konsep consumer well-being pada penelitian pemasaran, serta membangun proposisi terkait anteseden potensial consumer wellbeing dan konsekuensinya bagi luaran pemasaran. Melalui kajian mendalam dari berbagai literatur yang ada saat ini dapat disimpulkan bahwa CWB merupakan konstruk penting dalam penelitian pemasaran dan prilaku konsumen. Pengukuran CWB dapat dilakukan dengan mengukur kepuasan konsumsi yang berkontribusi terhadap beberapa keadaan positif konsumen yang berupa positive emotion, engagement, relationship, meaning, dan accomplishment (PERMA). Selain itu, artikel ini berhasil membangun proposisi bahwa brand authenticity dapat berpengaruh signifikan terhadap CWB dan luaran pemasaran yang berupa consumer citizenship behavior. Hubungan antar variabel tersebut didasarkan ada self-determination theory.
\end{abstract}

Kata kunci: Consumer Well-Being, Authenticity, Citizenship Behavior. 


\section{PENDAHULUAN}

Consumer Well-Being (CWB) mendapat banyak perhatian peneliti di bidang pemasaran saat ini (Carter, 2017; Falter \& Hadwich, 2019; Jian, Zhou, \& Zhou, 2019; Kim, Jeon, \& Hyun, 2012). Hal tersebut dikuatkan dengan berkembangnya Transformative Consumer /Service Research (TCR/TSR) sebagai sebuah gerakan akademis yang berusaha meneliti peran bisnis terhadap peningkatan Consumer WellBeing (CWB) (Davis \& Ozanne, 2018; Mick, Pettigrew, Pechmann, \& Ozanne, 2012). Selain itu, konsep Service Dominant Logic (SDL) (Vargo \& Lusch, 2008) juga muncul sebagai sebuah pendekatan baru dalam penelitian pemasaran yang juga berusaha mengkaji tentang bagaimana meningkatkan CWB melalui Value Co-Creation (Kuppelwieser \& Finsterwalder, 2016).

Di samping itu, perkembangan pasar saat ini menunjukkan bahwa konsumen lebih banyak menaruh perhatian pada aspek-aspek well-being baik yang berupa physical, social, financial, spiritual maupun environmental wellbeing (Crabbe, Lieberman, \& Moriarty, 2019; Mick et al., 2012; Sawyer, 2019; Varey \& Pirson, 2014). Perubahan perilaku konsumen tersebut dipicu oleh perkembangan teknologi informasi yang begitu pesat sehingga dapat menciptakan suatu kondisi pasar yang lebih terbuka dan transparan. Selain itu, perilaku generasi Millenial dan generasi $\mathrm{Z}$ juga menunjukkan kepedulian yang tinggi terhadap aspek-aspek well-being (Forbes,2018; Eggers, et al, 2013; Sawyer, 2019; Sheth \& Sisodia, 2005).

Sebuah studi multigenerasi yang dilakukan oleh Edelman Wellness 360 kepada 1.053 orang di Amerika menyimpulkan bahwa sebanyak 85 persen konsumen lebih memilih barang dan jasa dari perusahaan yang menaruh perhatian lebih terhadap CWB. Sebanyak 84 persen lainnya juga bersedia merekomendasikannya. Sedangkan 82 persen konsumen juga bersedia berbagi pendapat dan pengalaman positifnya terhadap produk dan jasa tersebut.

Menariknya, studi tersebut juga menyimpulkan bahwa sebanyak 66 persen konsumen ingin bekerja di perusahaan yang mampu mewujudkan atribut-atribut Well-Being dan sebanyak 58 persen lainnya bersedia meng- invesitasikan sumberdaya yang dimilikinya (Edelman, 2015). Dengan demikian dapat dikatakan bahwa CWB memiliki peran penting dalam perilaku konsumen (Sirgy, Lee, \& Rahtz, 2007), sehingga untuk memenangkan persaingan, seorang manager harus memberikan nilai yang superior dalam memenuhi kebutuhan dan keinginan konsumen melalui cara-cara yang berpotensi meningkatkan CWB (Kotler \& Armstrong, 2017).

Hingga saat ini belum terdapat kesepakan di antara para peneliti tentang apa yang dimaksud dengan CWB. Konsep CWB sering disamakan dengan konsep consumer satisfaction (Kim, Jeon, dan Hyun, 2012). Sementara kepuasan konsumen hanya merupakan respon positif atas kinerja suatu barang atau jasa setelah dibandingkan dengan ekpektasi konsumen (expectancy disconfirmation theory), di mana kepuasan justru tercipta dari ekspetasi yang tidak terkonfirmasi namun secara positif. Sebagai contoh, seorang konsumen memiliki ekspektasi yang rendah terhadap sebuah produk makanan berharga relatif murah, namun setelah dikonsumsi ternyata makanan tersebut memiliki rasa yang lebih enak dari ekspektasi (positive disconfirmation), sehingga muncul kepuasan dibenak konsumen. Meskipun demikian, karena kurangnya transparansi pemasar terkait bahan maupun proses produksi, ternyata mengkonsumsi produk tersebut memiliki dampak buruk secara langsung bagi fisik konsumen.

Contoh tersebut memberikan pemahaman bahwa meskipun sebuah produk dapat memberikan kepuasan bagi konsumen, namun tidak lantas dapat meningkatkan/mempertahankan CWB. Dengan kata lain kepuasan konsumen merupakan bagian dari CWB. Berkenaan dengan hal tersebut Zhao dan Wei (2019) memberikan label pada CWB sebagai "the higest hierarchy of consumptions".

Di sisi lain, terdapat kritik pada sepanjang perkembangan konsep maupun pengukuran CWB, di mana kebanyakan peneliti lebih menekankan prinsip ekonomi baik pada konsep maupun pengukuran CWB dan mengabaikan aspek-aspek sosial (Ahuvia, Scott, \& Izberk, 2010; Belk, 1985; Burroughs \& Rindfleisch, 2002; Deci \& Ryan, 2017; Diener \& Seligman, 
2004; Kasser \& Ahuvia, 2002; Malhotra, 2006; Sheth \& Sisodia, 2005).

Menurut Sirgy dan Lee (2008), CWB dapat dilihat dari sisi objektif maupun subjektif. Sisi objektif CWB dapat diketahui berdasarkan penilaian para ahli terkait kinerja suatu produk tertentu. Sedangkan sisi subjektif CWB dapat dilihat dari penilaian konsumen terhadap kepuasan suatu pengalaman konsumsi yang berkontribusi terhadap persepsi kepuasan hidupnya. Meskipun demikian, tren penelitian saat ini lebih banyak didominasi dengan kajian terhadap sisi subjektif CWB, maka artikel ini berusaha memberikan pemahaman lebih mendalam yang terbatas pada sisi subjektif CWB.

Lebih jauh, menurut Grzeskowiak \& Sirgy (2007) setiap produk memiliki dampak terhadap CWB baik secara positif maupun negatif, sehingga yang terpenting adalah bagaimana pemasaran dapat mendesain suatu pengalaman konsumsi yang dapat meningkat-kan CWB. Oleh karena itu, melalui kajian terhadap literatur-literatur yang ada saat ini, artikel ini juga bertujuan membangun proposisi tentang variabel-variabel yang berpotensi dapat mempengaruhi CWB yang berupa brand authenticity serta dampak CWB terhadap luaran pemasaran yang berupa consumer citizenship behavior.

\section{KAJIAN PUSTAKA}

\section{Perkembangan Konsep Consumer Well- Being dan Pemikiran Pemasaran}

Terdapat bukti sejarah bahwa CWB merupakan fokus utama kajian pemasaran pada tahun 1900-an, sebuah era di mana kajian pemasaran mulai dilakukan secara formal (Jones \& Monieson, 1990; Nason, 2011; Pancer \& Handelman, 2012; Shaw \& Jones, 2005; Wilkie \& Moore, 2012). Dalam masa tersebut, CWB dipahami melalui asumsi-asumsi ekonomi klasik dengan prinsip consumer sovereignty (kedaulatan konsumen) (Pancer \& Handelman, 2012), di mana kegiatan bisnis harus mampu memberikan manfaat ekonomi dan sosial baik bagi pemasar maupun konsumen (institutional school of thought).

Pergeseran paradigma pemasaran yang dimulai pada tahun 1950-an mengakibatkan pentingnya CWB sempat tidak lagi menjadi perhatian. Hal tersebut disebabkan karena studi pemasaran hanya berfokus pada peningkatan efisiensi ekonomi para manager dan organisasi/perusahaan saja (managerial school of thought). Berdasarkan filosofi reduksionisme, sistem pemasaran agregat juga dianggap dapat diturunkan menjadi bagian-bagian tertentu sesuai tujuan (functional school of thought) serta menganggap konsumen sebagai bagian eksogen dari sistem pemasaran (Pancer \& Handelman, 2012). Kondisi demikian menuai berbagai macam kritik baik dari kalangan akademik maupun non-akademik.

Di antara kritik yang pernah muncul dari kalangan activist school of thought seperti karya klasik Vance Packard "The Hidden Persuader" (1957) dan "The Waste Maker" (1960) (dalam Pancer \& Handelman, 2012). Kedua karya tersebut mengungkapkan adanya kekhawatiran publik terhadap kemampuan persuasif pemasar yang sangat baik dalam mempengaruhi prilaku masyarakat dengan memanifestasikan kebutuhan artifisial serta mengkomunikasikannya dengan metode yang manipulatif. Sebagaimana munculnya buyer /consumer behavior school of thought yang juga memanfaatkan aspek-aspek sosial budaya, psikologi eksperimental, psikologi konsumen, guna mendeteksi motivasi dan memanfaatkan bias konsumen agar dapat mengoptimalkan pemilihan konsumen (choice).

Demikian halnya dengan karya "Marketing Myopia" oleh Theodore Levitt (1960) yang menyebutkan bahwa kebanyakan pemasar hanya berfokus pada peningkatan penjualan dan mengabaikan hal-hal lainnya yang lebih luas. Selain itu, Wilkie dan Moore (2003) mengatakan bahwa di antara kritik-kritik pemasaran lainnya adalah efisiensi sistem pemasaran berkontribusi dalam berbagai masalah sosial seperti: "promoter of materialism, cultural value destroyer, fundamental manipulator, cultural imperialist, inequality driver, and self-serving egomaniac" (hal. 214).

Menghadapi kritik terhadap pemasaran yang begitu banyak, istilah pemasaran seakan menjadi sebuah stigma. Sebagaimana yang dikatakan oleh Wooliscroft (2014:53) bahwa “... the word 'Marketing', generally used, by 'uneducated' members of the population, to 
mean 'unethical people selling substandard goods at inflated prices' or 'misleading advertising,". Begitu pula Sheth dan Sisodia (2005) yang mengatakan bahwa marketing dapat kehilangan kredibilitasnya jika tidak direformasi untuk menyelesaikan masalahmasalah dilema moralitas, citra, serta 'marketer myopia. Di samping itu posisi manager pemasaran perlu dipertimbangkan kembali karena jika melihat perkembangan teknologi informasi saat ini sangat memungkinkan perubahan proses pemasaran kepada konsumen yang bersifat self-inform, self-evaluate, selfsegment, self-price, self-support, self-organize, self-advertise, self-police, dan self-program.

Lebih jauh, menurut Smith, Drumwright, dan Gentile (2010) meskipun para pemasar saat ini telah banyak memperbaiki diri dari "Marketing Myopia", namun "New Marketing Myopia" dapat muncul mana kala pemasar gagal untuk melihat suatu konteks sosial yang lebih luas. Pemasar juga harus berfokus pada stakeholder secara menyeluruh dan bukan hanya tentang pelanggan saja, memperluas definisi kebutuhan pelanggan, serta sadar terhadap perubahan konteks sosial yang ada.

Munculnya macromarketing school of thought pada tahun 1980-an menjadi titik balik pemikiran yang berusaha mengembalikan fungsi-fungsi pemasaran kepada masyarakat (Nason, 2011; Wilkie \& Moore, 1999, 2006, 2012). Hunt (1977) dalam (Nason, 2011) mengatakan bahwa macromarketing didefinisikan sebagai suatu kajian terhadap sistem pemasaran (marketing system) (Layton, 2019), serta kontribusinya bagi masyarakat baik yang bersifat positif maupun negatif dan/atau sebaliknya.

Dalam kajian macromarketing, konsep CWB dirumuskan dengan tingkat kepuasan konsumen dan choice atau assortment. Artinya konsumen dianggap sejahtera ketika menerima produk dengan kualitas yang tinggi, tidak adanya komplain, harga yang terjangkau, dan adanya nilai tambah. Namun demikian konsep ini dianggap masih mengandung pendapat ekonomi dan mengabaikan aspek-aspek sosial (Pancer \& Handelman, 2012). Sementara teori ekonomi sendiri memiliki keterbatasan dalam mengkaji fenomena kesejahteraan (well-being) yang begitu luas (Malhotra, 2006). Terdapat diskrepansi antara indikator ekonomi dan pengukuran well-being (Diener \& Seligman, 2004). Di samping itu, Ahuvia, Scott, dan Izberk (2010); Malhotra, (2006) mengungkapkan potensi kepuasan konsumen pada consumer life cycle (acquisition, preparation, consumption, ownership, maintenance, dan disposal) (Sirgy \& Lee, 2008) terhadap perilaku materialisme. Sedangkan materialisme justru dianggap dapat menurunkan tingkat well-being (Ahuvia et al., 2010; Belk, 1985; Burroughs \& Rindfleisch, 2002; Deci \& Ryan, 2017; Diener \& Seligman, 2004; Kasser \& Ahuvia, 2002; Malhotra, 2006).

Dengan mempertimbangkan aspek sejarah serta kritik terhadap pemasaran dan konseptualisasi CWB yang telah ada, maka dapat disimpulkan bahwa sebaiknya marketing harus kembali pada fungsi awalnya, di mana setiap aktifitas pemasaran memiliki kontribusi yang baik bagi semua pihak termasuk masyarakat. Hal tersebut dapat dilakukan dengan mempertimbangkan sisi subjektif CWB berdasarkan orientasi non ekonomi. Hal ini didasarkan pada pemikiran bahwa kesejahteraan (well-being) merupakan tujuan dan nilai akhir (ultimate goal/value) atas setiap aktifitas yang dilakukan manusia (Diener \& Seligman, 2002; Seligman, 2012).

Di samping itu pemasaran diyakini sangat berpotensi dalam meningkatkan kesejahteraan konsumen secara signifikan melalui penawaran barang dan jasa yang dapat meningkatkan kualitas hidup konsumen (Sirgy \& Lee, 2008). Kotler dan Armstrong (2017) menyatakan bahwa manager harus memberikan nilai yang superior dalam memenuhi kebutuhan dan keinginan konsumen melalui cara-cara yang berpotensi meningkatkan CWB.

Definisi pemasaran terbaru oleh AMA (American Marketing Association) sejak tahun 2007 yang menyatakan bahwa pemasaran merupakan aktifitas, seperangkat institusi, dan proses dalam menciptakan, mengkomunikasikan, menyampaikan, dan mempertukarkan suatu nilai bagi pelanggan, klien, rekanan, dan society at large (Gundlach \& Wilkie, 2009; Wilkie \& Moore, 2007). Penambahan society at large dalam domain pemasaran menjadikan setiap aktifitas maupun penelitian pemasaran 
agar memperhatikan aspek consumer wellbeing (Pancer \& Handelman, 2012).

Hal tersebut sejalan dengan Humanistic Paradigm baik dalam praktik, penelitian, maupun kebijakan pemasaran yang merupakan suatu pembaharuan yang lahir bersamaan dengan gerakan bisnis dan managemen yang humanis. Keduanya sama-sama mengedepankan nilai-nilai seperti altruism, empathy, respect, trustworthiness, honesty, integrity, care, compassion, service, intelligence, beauty, justice, dan virtue. Selain itu, paradigma tersebut juga berusaha menjawab apakah prinsip-prinsip dan praktik pemasaran dapat digunakan dalam membantu menjaga martabat (dignity) dan kesejahteraan (well-being) manusia.

Dengan demikian Marketing dapat menjadi sesuatu yang menghubungkan antara produksi dan konsumsi secara lebih beretika, sehingga martabat manusia dapat dilihat dari perilaku 'homo marketus' (Shultz dan Shapiro, 2014) sebagai makhluk yang senantiasa menciptakan, mengkomunikasikan, dan menebarkan serta mempertukarkan suatu nilai positif bagi sesama.

\section{Konsep Consumer Well-Being}

Pemahaman terhadap well-being dapat ditelusuri dari ajaran para filsuf Yunani Kuno yang melihat well-being melalui dua pendekatan yang berbeda yaitu Hedonic dan Eudaimonic Well-Being. Pendekatan Hedonic Well-Being dikemukakan oleh Aristippos (435 SM - 335 SM) yang berpendapat bahwa tujuan hidup adalah untuk mendapatkan kesenangan (pleasure) maksimal dan happiness adalah total momen-momen hedonis yang tercipta baik secara fisik maupun kognitif (Venhoeven, Bolderdijk, dan Steg, 2013). Hal tersebut membedakan secara jelas antara pleasure dan unpleasure atau afek positif dan afek negatif. Artinya, dalam menjalani kehidupannya seseorang sedapat mungkin menghindari halhal yang dapat menimbulkan perasaan unpleasure/pain atau afek negatif.

Pendekatan Eudaimonic Well-Being dikemukakan oleh Aristoteles (384 SM - 322 SM) yang berpendapat bahwa well-being mencerminkan kehidupan yang senantiasa menampilkan kapasitas terbaik manusia dengan berusaha mengikuti virtues dan excellences. Virtues dan excellences merupakan konsep yang mengandung makna keberanian (courages), sikap murah hati (generousity), kebijaksanaan atau hikmah (wisdom), dan keadilan, serta melakukan sesuatu yang bernilai secara intrinsik. Seseorang yang menjalani eudaimonic well-being senantiasa melakukan hal-hal yang bermoral berdasarkan alasan yang baik dan benar (Ryan dan Deci, 2001; Venhoeven et al., 2013). Hal tersebut membedakan secara jelas antara pleasure dan meaningfull. Artinya melakukan hal yang baik tidak selalu disertai dengan perasaan yang baik pula.

Kedua pendekatan filosofis tersebut juga digunakan dalam kajian psikologi. Pandangan hedonic approach lebih berfokus pada subjective well-being (SWB) atau yang sering disetarakan dengan konsep happiness (Diener, et al., 2010). Happiness diukur melalui beberapa konstruk seperti banyaknya afek positif, kurangnya afek negatif, dan seberapa tinggi tingkat kepuasan hidup yang dialami oleh individu (Diener, et al., 2010). Pandangan eudaimonic approach melihat bahwa wellbeing bukan sekedar happiness tetapi merupakan keberfungsian (functioning) kapasitas manusia secara penuh dan mencerminkan pembangunan manusia secara positif (personality atau self-actualization) (Ryan dan Deci, 2001; Ryff, 1989; Ryff dan Keyes, 1995; Ryff, Magee, Kling, dan Wing, 1999; Waterman, 1993). Dengan kata lain, perspektif eudaimonic lebih menekankan aspek psychological well-being (PWB). PWB diukur dengan menggunakan beberapa konstruk seperti self-acceptance, positive relations to others, autonomy, environmental mastery, purpose in life, dan personal growth (Ryff, 1989).

Perkembangan ilmu psikologi saat ini berpendapat bahwa kedua pandangan baik hedonic well-being maupun eudaimonic wellbeing sebenarnya tidak bertentangan. Keduanya justeru dapat saling mendukung dan melengkapi satu sama lain (Ryan dan Deci, 2001; Seligman, 2012; Venhoeven et al., 2013). Sesorang yang merasakan kebaikan dapat melakukan hal yang baik, demikian juga ketika seseorang yang melakukan hal baik dapat 
meraih perasaan yang baik pula (Venhoeven et al., 2013). Penelitian Taylor (2014) dalam Jian et al. (2019) mengkonfirmasi bahwa hedonic dan eudaimonic well-being memiliki korelasi antara satu sama lain. Kedua pendekatan tersebut melibatkan teori positive psychology (Seligman, 2012) yang merupakan salah satu pengembangan terbaru dalam memahami CWB di luar pendapat-pendapat ekonomi (Pancer dan Handelman, 2012).

Adapun konstruk well-being berupa positive emotion, engagement, relationship, meaning, dan accomplishment atau yang lebih dikenal dengan istilah PERMA (Seligman, 2012). Penjelasan masing-masing konstruk/dimensi PERMA antara lain:

a. Positive Emotion menggambarkan suatu keadaan emosi positif seperti perasaan senang, riang, atau bahagia.

b. Engagement merupakan gambaran seseorang yang mampu melakukan aktifitas dengan baik, memiliki ketertarikan dan gairah terhadap kesehariannya.

c. Relationship menggambarkan kualitas hubungan yang positif dengan lingkungan sosialnya.

d. Meaning merupakan kepercayaan bahwa hidup yang dijalani seseorang lebih bermakna dan merasa terhubung dengan sesuatu yang lebih tinggi.

e. Accomplisment menjelaskan kemampuan seseorang dalam pencapaian-pencapaian atau kesuksesan pada aktifitas sehari-hari.

Berdasarkan pendapat-pendapat tersebut maka, konsep CWB yang digunakan adalah suatu keadaan positif konsumen yang tidak hanya mencerminkan tingkat kebahagiaan tetapi juga keberfungsian kapasitas manusia secara penuh. Hal tersebut melibatkan komponen-komponen afektif dan kognitif. Menurut Falter \& Hadwich (2019) komponen afektif merupakan keseimbangan antara afek positif dan negatif seperti kepuasan pada pengalaman konsumsi. Sedangkan komponen kognitif merupakan tingkat kepuasan hidup seseorang. Dengan demikian dapat dikatakan bahwa CWB merupakan pertautan antara kepuasan konsumsi suatu barang atau jasa terhadap kepuasan hidup konsumen (Sirgy \& Lee, 2008).
Dengan demikian CWB dapat dilihat ketika konsumen memiliki beberapa kualitas yang baik seperti, emosi positif, engage terhadap hal-hal yang penting bagi dirinya, tidak bersikap anti sosial, memiliki kebermaknaan hidup, serta memiliki efikasi yang baik.

\section{Konsep Brand Authenticity}

Beberapa perspektif yang menjelaskan tentang perbedaan konsep authenticity di antaranya, perspektif objectivist, constructivist, dan existentialist (Morhart, et al., 2014). Perspektif objectivist berpendapat bahwa authenticity merupakan gambaran penilaian kualitas yang melekat pada suatu objek oleh para ahli. Otentisitas jenis ini disebut dengan indexical authenticity (Grayson \& Martinec, 2004). Suatu objek dianggap otentik jika secara indeksikal dapat dibedakan dengan tiruannya. Indexicality yang dimaksud merupakan persepsi seseorang terhadap kenyataan pengalaman fisik atau prilaku suatu objek yang diverifikasi berdasarkan apa yang diklaim sebelumnya. Hal tersebut dapat berupa informasi objektif seperti sertifikat keaslian, usia, komposisi dan kinerja aktualnya (Morhart, et al., 2014).

Perspektif constructivist berpandangan bahwa authenticity merupakan suatu fenomena yang dikonstruksikan baik secara sosial maupun personal (Morhart et al., 2014). Artinya, suatu otentisitas bukanlah merupakan kualitas yang melekat pada suatu objek, namun merupakan proyeksi atas suatu kepercayaan, ekspektasi, dan perspektif seseorang. Otentisitas pada jenis ini disebut juga dengan iconic authenticity (Grayson \& Martinec, 2004).

Sedangkan perspektif existentialist didasarkan pada filosofi eksistensialisme yang berusaha mengkaitkan otentisitas dengan konsep true self (Kernis \& Goldman, 2006). Dalam perspektif ini, suatu otentisitas tercipta ketika objek tertentu dipandang mampu memandu seseorang untuk menemukan jati dirinya (Morhart et al., 2014). Dengan kata lain suatu produk dianggap otentik ketika sesuai dengan nilai-nilai diri konsumen.

Menurut Moulard, Raggio, \& Folse (2016) Authenticity merupakan salah satu strategi pemasaran yang berorientasi pada produk. 
Artinya produk yang ditawarkan lebih mencerminkan kepentingan dan keahlian perusahaan dari pada kebutuhan dan keinginan konsumen. Berdasarkan self-determination theory penulis tersebut mendefinisikan Authenticity sebagai persepsi konsumen tentang sejauh mana manager atau penyedia barang dan jasa memiliki motivasi intrinsik. Hal tersebut berkaitan dengan passion dan menjadikan suatu produk sebagai sebuah persembahan kepada konsumen. Authenticity pada jenis ini berfokus pada prilaku karyawan/perusahaan.

Menurut Fritz, Schoenmueller, \& Bruhn (2017) authenticity dapat didefinisikan sebagai persepsi konsumen terhadap konsistensi prilaku brand dengan nilai inti dan norma yang dibangun dari brand tersebut. Dengan kata lain authenticity berkaitan dengan kejujuran sebuah brand yang telah bertahan cukup lama. Penciptaan persepsi tersebut melibatkan indexical dan iconic authenticity. Dalam hal ini, Authenticity juga berfokus pada prilaku organisasi dan produk yang ditawarkan.

Menurut Morhart, et al. (2014) Authenticity merupakan persepsi konsumen tentang sejauh mana kesetiaan dan kebenaran suatu brand terhadap nilai-nilai organsasi dan konsumennya, serta mampu membantu mengekpresikan nilai diri konsumen. Pendapat tersebut tidak hanya melibatkan authenticity secara indeksikal dan iconic saja, tetapi juga secara existensialist. Dengan kata lain, authenticity tidak hanya dilihat dari kualitas produk dan prilaku organisasi saja, tetapi juga mempertimbangkan nilai-nilai konsumen.

Menurut Bruhn, et al. (2012) dimensi BA dapat berupa Continuity, Originality, Naturalness, dan Reliability. Sedangkan menurut Morhart, et al. (2014) dimensi BA dapat berupa Continuity, Credibility, Integrity dan Symbolism. Dimensi-dimensi BA dari kedua peneliti tersebut memiliki kesamaan konsep, di mana kedua peneliti tersebut samasama menggunakan dimensi Continuity. Dimensi Reliability (Bruhn, et al., 2012) dan Credibility (Morhart, et al., 2014) memiliki kemiripan pada indikator pembentuknya, di mana keduanya sama-sama merefleksikan komitmen perusahaan terhadap janji-janjinya. Dengan demikian dapat disimpulkan bahwa dimensi-dimensi yang membentuk BA adalah sebagai berikut :

a. Continuity adalah dimensi otentisitas yang mencerminkan kualitas produk yang tidak terpengaruh oleh waktu (Bruhn, et al., 2012; Morhart, et al., 2014)

b. Naturalness meliputi persepsi konsumen terhadap keaslian, realness, dan bersikap apa adanya (Bruhn, et al., 2012).

c. Credibility berkaitan dengan nilai-nilai seperti kejujuran, kredibilitas dan menepati janji (Morhart, et al., 2014)

d. Integrity mencerminkan integritas atau sikap dapat dipercaya dan bertanggung jawab (Morhart, et al., 2014).

e. Symbolism berkaitan dengan seberapa baik suatu brand dalam mencerminkan nilainilai yang penting bagi konsumen (Morhart, et al., 2014)

\section{Konsep Consumer Citizenship Behavior}

Consumer Citizenship Behavior merupakan sintesis dari teori Organisational Citizenship Behavior (Groth, 2005; Groth, Mertens, dan Murphy, 2014). Prilaku citizenship dipahami sebagai suatu prilaku yang dilakukan secara suka rela dan bijaksana, atau sebagai peran ekstra pegawai dalam meningkatkan efektifitas organisasi (Organ, 1988 dalam Bavik, 2019). Sedangkan CCB melibatkan beberapa prilaku yang dilakukan secara suka rela oleh konsumen dan memberikan dampak positif bagi kinerja suatu organisasi (Groth, 2005; Groth et al., 2014). Hal tersebut dapat berupa perilaku konsumen yang membantu tugas karyawan tertentu maupun membantu konsumen lainnya (Tung, Chen, \& Schuckert, 2017).

$C C B$ dapat memberikan dampak positif bagi organisasi seperti meningkatkan kinerja, kepuasan kerja, dan komitmen karyawan (Yi, Nataraajan, \& Gong, 2011). Sehingga hal tersebut dapat menurunkan tingkat turnover intention (Revilla-Camacho et al., 2015; Yi et al., 2011). Menurut Batencourt (1997) dalam Tung et al. (2017) CCB dapat berupa loyalitas, cooperation, dan participation. Groth (2005) juga menambahkan tiga dimensi lainnya seperti rekomendasi, feedback, dan membantu konsumen lain untuk mendapatkan apa yang diinginkan atau dibutuhkan. Selain itu, $C C B$ 
juga dapat berupa advocacy dan toleransi terhadap pelayanan yang kurang memuaskan (Revilla-Camacho, Vega-Vázquez, \& CossíoSilva, 2015). Prilaku-prilaku positif tersebut sejalan dengan paradigma Humanistic Marketing yang mengedepankan beberapa nilai-nilai positif seperti altruism, empathy, respect, trustworthiness, honesty, integrity, care, compassion, service, intelligence, beauty, justice, dan virtue (Varey \& Pirson, 2014).

Pengukuran Consumer Citizenship Behavior ini dapat diketahui dengan mengukur respon konsumen terhadap beberapa indikator Consumer Citizenship Behavior yang diadaptasi dari penelitian Yi dan Gong (2013) yang berupa feedback, advocacy, helping behavior, dan tolerance. Penjelasan masingmasing dimensi antara lain:

a. Feedback merupakan informasi yang diberikan konsumen kepada karyawan baik diminta maupun tidak diminta. Informasi tersebut dapat memberikan manfaat kepada perusahaan dalam meningkatkan kualitas.

b. Advocacy merupakan pemberian rekomendasi baik tentang perusahaan, karyawan, atau produk kepada teman atau keluarga.

c. Helping Behavior merupakan kemauan konsumen untuk membantu konsumen lain dalam mendapatkan apa yang mereka butuhkan.

d. Tolerance merupakan kemauan konsumen untuk bersikap sabar atas ketidak sesuaian layanan yang diberikan dengan harapan konsumen.

\section{Hubungan Antar Variabel}

Pengaruh Brand Authenticity (BA) terhadap Consumer Well-Being (CWB)

Beberapa fenomena seperti krisis finansial, perubahan iklim, dan isu-isu moral yang diakibatkan oleh kesalahan managerial menyebabkan tuntutan konsumen terhadap $B A$ meningkat (Bruhn, et al., 2012). Menurut Beverland \& Farrelly (2010) saat ini konsumen dihadapkan dengan arus globalisasi, perubahan zaman yang begitu cepat, serta upaya homogenisasi pasar. Hal tersebut mengakibatkan banyaknya bermunculan barang-barang tiruan sehingga suatu produk yang mengandalkan dimensi kualitas saja sebagai bentuk diferensiasi dinilai tidak cukup (Le, et al., 2019). Dengan demikian otentisitas dianggap sebagai alternatif yang dapat menggantikan aspek kualitas (Gilmore dan Pine II, 2007).

Otentisitas diperoleh sepanjang memiliki kinerja produk yang baik sesuai apa yang diklaim oleh perusahaan (indexical). Selain itu otentitas secara iconic diperoleh sepanjang brand terkait mampu mencerminkan nilai-nilai yang berkembang di masyarakat dari waktu ke waktu, serta dapat diperoleh ketika suatu brand mampu mencerminkan nilai diri konsumennya (existensialist).

Menurut Self-Determination Theory kondisi Well-Being dapat tercipta ketika kebutuhan psikologi dasar seseorang terpenuhi. Kebutuhan psikologi dasar (Basic Psychological Needs) yang dimaksud berupa Autonomy, Competance, dan Relatedness (Deci \& Ryan, 2017). Menurut Deci \& Ryan (2017) Autonomy dapat dipahami sebagai kebijaksanaan diri yang ditandai dengan tidak adanya konflik dalam diri seseorang. Sedangkan BA merupakan salah satu bentuk realisasi diri (selfrealization) atau mampu mencerminkan pilihan konsumen yang sesuai dengan konsep dirinya (self-congruence) (Fritz et al., 2017). Dengan demikian, otentisitas dapat memenuhi kebutuhan psikologi dasar konsumen berupa autonomy yang pada gilirannya akan mempengaruhi Consumer Well-Being.

Selain itu, Brand dengan tingkat otentisitas yang tinggi memiliki beberapa beberapa karakteristik seperti keunikan, dapat dipercaya, dan memiliki jaminan kualitas serta dapat mempengaruhi emosi positif konsumen yang pada akhirnya dapat meningkatkan kepuasan hidup konsumen (Jian, et al., 2019). Pendapat tersebut dikonfirmasi oleh hasil penelitian Jian, et al., (2019) yang menyimpulkan bahwa BA berpengaruh positif terhadap Consumer Eudaimonic dan Hedonic Well-Being.

Penelitian yang dilakukan oleh Grzeskowiak dan Sirgy (2007) menyatakan bahwa Self-Image Congruence berpengaruh positif terhadap CWB. Esensi dari temuan tersebut menunjukkan bahwa konsumen merasakan kesesuaian antara Brand Image dengan nilai dirinya. Dengan kata lain, konsumen tersebut merasakan pengalaman 
Authenticity secara eksistensialis sehingga dapat mempengaruhi CWB. Sejalan dengan studi tersebut beberapa penelitian terdahulu juga berhasil menyimpulkan bahwa CWB dipengaruhi secara signifikan oleh Brand Community Belongingness (Grzeskowiak \& Sirgy, 2007), Brand Attitude (Kim et al., 2012), Brand Cultural Symbolism (Jian et al., 2019).

Berdasarkan uraian baik tentang konsep maupun penelitian empiris, maka dapat diduga bahwa BA berpengaruh signifikan terhadap CWB. Dengan demikian proposisi yang dapat dibangun adalah sebagai berikut :

Proposisi 1: Brand Authenticity berpengaruh signifikan terhadap Consumer Well-Being.

\section{Pengaruh Brand Authenticity terhadap Consumer Citizenship Behavior}

CCB merupakan salah satu prilaku prososial yang dilakukan oleh konsumen baik kepada perusahaan/karyawan maupun konsumen lain dan berdampak positif bagi perusahaan (Groth, 2005; Organ, Podsakoff, dan MacKenzie, 1983; Yi dan Gong, 2008). CCB setidaknya dapat berupa feedback, advocacy (rekomendasi), helping behavior (membantu karyawan atau konsumen lain), dan tolerance atas ketidak sesuaian layanan yang diberikan (Yi dan Gong, 2013). Sedangkan dampak positif CCB bagi perusahaan dapat berupa peningkatan kinerja, kepuasan kerja, dan komitmen karyawan (Yi, et al., 2011), serta menurunkan tingkat turn over intention (Revilla-Camacho, Vega-Vázquez, dan CossíoSilva, 2015; Yi, et al., 2011).

Sejauh pengetahuan peneliti, pengaruh authenticity terhadap consumer citizenship behavior belum pernah diteliti. Meskipun demikian jika melihat dimensi-dimensi CCB yang dapat berupa loyalitas, positive word of mouth, dan advocacy (Groth 2005; RevillaCamacho et al,. 2015; Tung et al., 2017), maka dapat dikatakan bahwa authenticity dapat mempengaruhi CCB. Hal tersebut dapat dilihat dari hasil penelitian-penelitian yang berusaha mengetahui pengaruh authenticity terhadap dimensi-dimensi CCB. Sebagaimana hasil penelitian Busser dan Shulga (2019) yang menyimpulkan bahwa Authenticity berpengaruh signifikan terhadap Loyalitas Konsumen. Bartikowski dan Walsh (2011) menyimpulkan bahwa $\mathrm{CCB}$ dapat dipengaruhi oleh Corporate Reputation. Demikian juga Bove, et al. (2009) menyatakan bahwa CCB dapat dipengaruhi oleh kredibilitas karyawan. Sedangkan Bavik (2019) menyimpulkan bahwa CCB dapat dipengaruhi oleh Corporate Social Responsibility. Selain itu, Dang dan Arndt (2017) mengatakan bahwa salah satu hal yang juga dapat mempengaruhi CCB adalah normanorma yang berlaku. Oleh karena itu dapat diduga bahwa brand authenticity menjadi faktor eksternal yang mempengaruhi CCB.

Dengan demikian dapat dikatakan bahwa Authenticity dapat berpengaruh signifikan terhadap dimensi $C C B$. Oleh karena itu proposisi ke-dua yang dapat dibangun adalah sebagai berikut :

Proposisi 2: Brand authenticity berpengaruh signifikan terhadap Consumer Citizenship Behavior.

Pengaruh Consumer Well-Being terhadap Consumer Citizenship Behavior

Penelitian terdahulu menyimpulkan bahwa faktor-faktor yang dapat mempengaruhi CCB di antaranya seperti CSR (Bavik, 2019), personality dan social support baik dari organisasi maupun konsumen lain (Hwang dan Lee, 2019; Yi et al., 2013, 2011), serta kepuasan dan komitmen konsumen (Yi \& Gong, 2009). Hal tersebut didasarkan pada teori pertukaran sosial (social exchange theory) yang melibatkan hubungan resiprokal antara satu pihak dengan pihak yang lain (Yi dan Gong, 2009). Jika didasarkan pada teori pertukaran sosial yang melibatkan hubungan resiprokal maka dapat dikatakan bahwa CWB dapat mempengaruhi CCB. Hal tersebut sejalan dengan pendapat Sirgy dan Lee (2008) yang mengatakan bahwa jika suatu perusahaan yang berkomitmen untuk meningkatkan kualitas hidup konsumennya maka, konsumen tersebut akan meresponnya dengan prilaku-prilaku positif. Selain itu, menurut self-determination theory seseorang yang memiliki tingkat well-being yang tinggi maka akan lebih menunjukkan prilaku positif seperti altruistic, compassion, emphaty dan sifat-sifat positif lainnya.

Di sisi lain beberapa penelitian lainnya juga berhasil mengungkapkan bahwa CWB berpengaruh signifikan terhadap Choice atau 
pilihan pelanggan (Mogilner, Aaker, \& Kamvar, 2012), Behavioral Intention (Kim et al., 2012), Brand loyalty (Troebs, Wagner, \& Heidemann, 2018) dan positive Word-of-Mouth (Schnebelen\& Bruhn, 2018). Wooliscroft dan Wooliscroft (2017) menyatakan seseorang yang mengalami sense of eudaimonic well-being lebih menunjukkan kemauan untuk berprilaku etis dalam mengkonsumsi (ethical consumptions) dari pada seseorang yang sekedar mengalami kepuasan (hedonic experience).

Dengan demikian dapat diduga bahwa CWB berpengaruh terhadap CCB. Oleh karena itu, proposisi ke-tiga yang dapat dibangun sebagai berikut:

Proposisi 3: Consumer Well-Being berpengaruh signifikan terhadap Consumer Citizenship Behavior.

\section{METODE PENELITIAN}

Artikel ini bertujuan untuk memberikan pemahaman yang lebih mendalam terkait konsep consumer well-being, brand authenticity, dan consumer citizenship behavior. Selain itu, artikel ini juga hendak membangun proposi-proposisi terkait hubungan antar konsep-konsep tersebut. Adapun untuk mencapai tujuan yang dimaksud, dilakukan kajian terhadap literatur-literatur dengan kata kunci consumer well-being, wellbeing, brand authenticity, customer citizenship behavior. Literatur-literatur yang diperoleh berasal dari electronic database Elsevier dan Emerald, serta artikel-artikel terindeks Google Scholar yang relevan.

\section{KESIMPULANDAN SARAN Kesimpulan}

Berdasarkan kajian literatur yang ada saat ini, dapat disimpulkan bahwa CWB memiliki peran penting terhadap prilaku konsumen. Meskipun demikian konsep CWB sebelumnya didominasi oleh exchange paradigm yang berusaha mengukur CWB melalui pendekatan ekonomi. Selain itu, CWB sering disetarakan dengan konsep kepuasan konsumen, sementara konsep tersebut hanya memenuhi sisi hedonic well-being. Dengan demikian konsep consumer well-being pada penelitian ini menggunakan pendekatan dari teori positive psychology yang tidak hanya melibatkan sisi hedonic saja tetapi juga eudaimonic well-being. Hal tersebut sesuai dengan pendapat Pancer dan Handelman (2012) yang mengatakan bahwa teori psikologi positif merupakan salah satu pendekatan terbaru untuk memahami CWB. CWB dapat berupa kepuasan konsumsi dan kontribusinya terhadap beberapa keadaan positif konsumen yang berupa positive emotion, engagement, relationship, meaning, dan accomplishment (PERMA).

Variabel yang berpotensi sebagai anteseden CWB dapat berupa Brand Authenticity, di mana berdasarkan selfdetermination theory bahwa brand authenticity dapat memenuhi kebutuhan psikologi dasar konsumen yang berupa autonomy, competence dan relatedness yang penting bagi CWB. Sehingga dapat dibangun proposisi bahwa brand authenticity berpengaruh signifikan terhadap consumer well-being. Adapun konstruk pengukuran brand authenticity berupa continuity, credibility, naturalness, integrity, dan symbolism.

Selain itu dari literatur yang ada dapat diduga bahwa CWB dapat berdampak pada consumer citizenship behavior. Hal tersebut didasarkan pada teori pertukaran sosial (social exchange theory) di mana perusahaan yang berkomitmen untuk meningkatkan kualitas hidup konsumennya maka, konsumen tersebut akan meresponnya dengan prilaku-prilaku positif. Selain itu, menurut self-determination theory seseorang yang memiliki tingkat wellbeing yang tinggi maka akan lebih menunjukkan prilaku positif seperti altruistic, compassion, emphaty dan sifat-sifat positif lainnya. Adapun bentuk-bentuk consumer citizenship behavior dapat berupa feedback, advocacy, helping behavior, dan tolerance. Meskipun demikian pengaruh antara keduanya belum teruji secara empiris, sehingga perlu diteliti lebih lanjut.

\section{Saran}

Kajian literatur pada artikel ini telah berhasil mengungkapkan pentingnya CWB pada penelitian pemasaran dan perilaku konsumen. Selain itu, artikel ini juga berhasil membangun proposisi terkait salah satu faktor yang dapat mempengaruhi CWB yaitu variabel brand authenticity. Serta bagaimana kedua 
variabel tersebut dapat berpengaruh terhadap customer citizenship behavior yang pada akhirnya dapat memberikan implikasi managerial.

Meskipun demikian, artikel ini masih menyisakan berbagai pertanyaan terkait konsep-konsep yang telah diuraikan. Sebagai contoh, apakah ada perbedaan antara konsep CWB pada setiap kategori produk?, apakah kontruk pengukuran CWB berdasarkan perspektif Positif psikologi harus dilakukan secara multi-dimensional?, perlukah melakukan pengukuran CWB secara longitudinal?. Dengan mempertimbangkan keterbatasan peneliti, maka penelitian selanjutnya diharapkan dapat menjawab pertanyaan-pertanyaan tersebut.

\section{DAFTAR PUSTAKA}

Ahuvia, A., Scott, C., \& Izberk, E. (2010). Consumer Well-Being. In Wiley International Encyclopedia of Marketing. Jhon Wiley \& Sons Ltd.

Bavik, A. (2019). Corporate social responsibility and service-oriented citizenship behavior: A test of dual explanatory paths. International Journal of Hospitality Management, 80(October 2018),

173-182. https://doi.org/10.1016/j.ijhm.2018.11.01 4

Belk, R. W. (1985). Materialism: Trait Aspects of Living in the Material World. Journal of Consumer Research, 12(3), 265. https://doi.org/10.1086/208515

Beverland, M. B., \& Farrelly, F. J. (2010). The Quest for Authenticity in Consumption: Consumers' Purposive Choice of Authentic Cues to Shape Experienced Outcomes. Journal of Consumer Research, 36(5), 838-856. https://doi.org/10.1086/615047

Bruhn, M., Schoenmüller, V., Schäfer, D., \& Heinrich, D. (2012). Brand authenticity: towards a deeper understanding of its conceptualization and measurement. In G.-C. Zeynep, O. Cele, \& Z. Rui (Juliet) (Ed.), NA-Advance in Consumer ResearchAdvances of Consumer Research (Vol. 40, hal. 567-576). Duluth, MN: Association for Consumer Research.
Diambil dari http://www.acrwebsite.org/volumes/1013 106/volumes/v40/NA-

40http://www.copyright.com/.

Burroughs, J. E., \& Rindfleisch, A. (2002). Materialism and Well-Being: A Conflicting Values Perspective. Journal of Consumer Research, 29(3), 348-370. https://doi.org/10.1086/344429

Busser, J. A., \& Shulga, L. V. (2019). Involvement in consumer-generated advertising: Effects of organizational transparency and brand authenticity on loyalty and trust. International Journal of Contemporary Hospitality Management, 31(4), 1763-1784. https://doi.org/10.1108/IJCHM-10-20170685

Carter, L. E. P. (2017). A Dynamic and MultiDimensional Approach to Consumer Well-Being. UNiversity of Colorado.

Consumer Trends in Health and Wellness. (n.d.). Diambil 6 Desember 2019, dari https://www.forbes.com/sites/thehartman group/2015/11/19/consumer-trends-inhealth-and-wellness/\#663bd494313e

Crabbe, M., Lieberman, G., \& Moriarty, S. (2019). Global Consumer Trends 2030. Diambil dari https://www.mintel.com/globalconsumer-trends

Davis, B., \& Ozanne, J. L. (2018). Measuring the impact of transformative consumer research: The relational engagement approach as a promising avenue. Journal of Business Research, 100(December 2018), 311-318. https://doi.org/10.1016/j.jbusres.2018.12. 047

Davis, B., Ozanne, J. L., \& Hill, R. P. (2016). The Transformative Consumer Research Movement. Journal of Public Policy and Marketing, 1-27.

Davis, B., \& Pechmann, C. (2013). Introduction to the Special Issue on transformative consumer research: Developing theory to mobilize efforts that improve consumer and societal well-being. Journal of Business Research, 66(8), 1168-1170. https://doi.org/10.1016/j.jbusres.2012.08. 008 
Deci, E. L., \& Ryan, R. M. (2017). SelfDetermination Theory: Basic Psychological Needs in Motivation Development and Wellness. New York: Guilford Publishing. New York: The Guilford Press. https://doi.org/10.1097/TA.0b013e31827 e1534

Diener, E., Ng, W., Harter, J., \& Arora, R. (2010). Wealth and Happiness Across the World: Material Prosperity Predicts Life Evaluation, Whereas Psychosocial Prosperity Predicts Positive Feeling. Journal of Personality and Social Psychology, 99(1), 52-61. https://doi.org/10.1037/a0018066

Diener, E., \& Seligman, M. E. P. (2002). Very happy people. Psychological Science, 13(1), 81-84. https://doi.org/10.1111/1467-9280.00415

Diener, E., \& Seligman, M. E. P. (2004). Beyond Money: Progress on an Economy of Well-Being. Psychological Science in the Public Interest, 5(1), 1-31. https://doi.org/10.1177/17456916166894 67

Edelman. (2015). New Edelman Study Reveals Americans Face a Dilemma in Their Pursuit of Well-Being. Diambil 8 Februari 2020, dari https://www.edelman.com/newsawards/new-edelman-study-revealsamericans-face-dilemma-their-pursuitwell-being

Eggers, F., O’Dwyer, M., Kraus, S., Vallaster, C., \& Güldenberg, S. (2013). The impact of brand authenticity on brand trust and SME growth: A CEO perspective. Journal of World Business, 48(3), 340-348. https://doi.org/10.1016/j.jwb.2012.07.018

Falter, M., \& Hadwich, K. (2019). Customer service well-being: scale development and validation. Service Industries Journal, 40(1-2), 181-202. https://doi.org/10.1080/02642069.2019.1 652599

Fritz, K., Schoenmueller, V., \& Bruhn, M. (2017). Authenticity in branding exploring antecedents and consequences of brand authenticity. European Journal of MarketingEuropean Journal of
Marketing, 51(2), 324-348. https://doi.org/10.1108/EJM-10-20140633

Gilmore, J. H., \& Pine II, B. J. (2007). Authenticity: What Consumer Really Want (1 ed.). Boston, Massachusetts: Harvard Business School Press.

Grayson, K., \& Martinec, R. (2004). Consumer Perceptions of Iconicity and Indexicality and Their Influence on Assessments of Authentic Market Offerings. Journal of Consumer Research, 31(2), 296-312. https://doi.org/10.1086/422109

Groth, M. (2005). Customers as good soldiers: Examining citizenship behaviors in internet service deliveries. Journal of Management, 31(1), 7-27. https://doi.org/10.1177/01492063042713 75

Groth, M., Mertens, D. P., \& Murphy, R. O. (2014). Customers as good soldiers: Extending organizational citizenship behavior research to the customer domain. In D. L. Turnipseed (Ed.), Handbook of Organizational Citizenship Behavior (hal. 415-433). Nova Science Publishers, Inc.

Grzeskowiak, S., \& Sirgy, M. J. (2007). Consumer Well-Being (CWB): The Effects of Self-Image Congruence, BrandCommunity Belongingness, Brand Loyalty, and Consumption Recency. Applied Research in Quality of Life, 2(4), 289-304. https://doi.org/10.1007/s11482008-9043-9

Gundlach, G. T., \& Wilkie, W. L. (2009). The American marketing association's new definition of marketing: Perspective and commentary on the 2007 revision. Journal of Public Policy and Marketing, 28(2), 259-264. https://doi.org/10.1509/jppm.28.2.259

Hair, J. F., Hult, G. T. M., Ringle, C. M., \& Sarstedt, M. (2017). A Primer on Partial Least Squares Structural Equation Modeling ( PLS-SEM ) (2 ed.). USA: SAGE Publications, Inc.

Hwang, K., \& Lee, B. (2019). Pride, mindfulness, public self-awareness, affective satisfaction, and customer citizenship behaviour among green restaurant customers. International 
Journal of Hospitality Management, 83(December 2018), 169-179. https://doi.org/10.1016/j.ijhm.2019.05.00 9

Jian, Y., Zhou, Z., \& Zhou, N. (2019). Brand cultural symbolism, brand authenticity, and consumer well-being: the moderating role of cultural involvement. Journal of Product and Brand Management, 28(4), 529-539. https://doi.org/10.1108/JPBM08-2018-1981

Jones, D. G. B., \& Monieson, D. D. (1990). Early Development of Philosophy of Marketing Thought. Journal of Marketing, 54(1), 102-113.

Kasser, T., \& Ahuvia, A. (2002). Materialistic values and well-being in business students. European Journal of Social Psychology, 32(1), 137-146. https://doi.org/10.1002/ejsp.85

Kernis, M. H., \& Goldman, B. M. (2006). A Multicomponent Conceptualization of Authenticity: Theory and Research. Advances in Experimental Social Psychology, 38(06), 283-357. https://doi.org/10.1016/S00652601(06)38006-9

Kim, I., Jeon, S. M., \& Hyun, S. S. (2012). Chain restaurant patrons' well-being perception and dining intentions: The moderating role of involvement. International Journal of Contemporary Hospitality Management, 24(3), 402-429. https://doi.org/10.1108/09596111211217 888

Kotler, P., \& Armstrong, G. (2017). Principles of Marketing (17th ed.). United Kingdom: Pearson Education Limited.

Kuppelwieser, V. G., \& Finsterwalder, J. (2016). Transformative service research and service dominant logic: Quo Vaditis? Journal of Retailing and Consumer Services, 28(October 2017), 91-98. https://doi.org/10.1016/j.jretconser.2015. 08.011

Layton, R. A. (2019). Marketing Systems Looking Backward, Sizing up and Thinking Ahead. Journal of Macromarketing, $\quad X X(\mathrm{X}), \quad 1-17$. https://doi.org/10.1177/02761467188238 97
Le, T. H., Arcodia, C., Novais, M. A., \& Kralj, A. (2019). What we know and do not know about authenticity in dining experiences: A systematic literature review. Tourism Management, 74(February), 258-275. https://doi.org/10.1016/j.tourman.2019.02 .012

Levitt, T. (1960). Marketing Myopia. Harvard Business Review, Vol.38, 45-56.

Malhotra, N. K. (2006). Consumer well-being and quality of life: An assessment and directions for future research. Journal of Macromarketing, 26(1), 77-80. https://doi.org/10.1177/02761467052859 70

Mick, D. G., Pettigrew, S., Pechmann, C., \& Ozanne, J. L. (2012). Transformative Consumer Research for Personal and Collective Well-Being. New York, London: Routledge.

Mogilner, C., Aaker, J., \& Kamvar, S. D. (2012). How Happiness Affects Choice. Journal of Consumer Research, 39(2), 429-443. https://doi.org/10.1086/663774

Morhart, F., Malär, L., Guèvremont, A., Girardin, F., \& Grohmann, B. (2014). Brand authenticity: An integrative framework and measurement scale. Journal of Consumer Psychology, 25(2), 200-218.

https://doi.org/10.1016/j.jcps.2014.11.00 6

Moulard, J. G., Raggio, R. D., \& Folse, J. A. G. (2016). Brand Authenticity: Testing the Antecedents and Outcome of Brand Management's Passion for its Products. Psychology \& Marketing, 33(6), 421-436. https://doi.org/DOI: 10.1002/mar.20888

Nason, R. W. (2011). Institutionalization of Macromarketing. Journal of Historical Research in Marketing, 3(2), 261-268.

Organ, D. W., Podsakoff, P. M., \& MacKenzie, S. B. (1983). Organizational citizenship behavior: Its nature and antecedents. Journal of Applied Psychology, 68(4), 653-663.

Pancer, E., \& Handelman, J. (2012). The evolution of consumer well-being. Journal of Historical Research in Marketing, 4(1), 177-189. 
https://doi.org/10.1108/17557501211195 118

Revilla-Camacho, M. Á., Vega-Vázquez, M., \& Cossío-Silva, F. J. (2015). Customer participation and citizenship behavior effects on turnover intention. Journal of Business Research, 68(7), 1607-1611. https://doi.org/10.1016/j.jbusres.2015.02. 004

Ryan, R. M., \& Deci, E. L. (2001). On Happiness and Human Potentials: A Review of Research on Hedonic and Eudaimonic Well-Being. Annual review Psycology, 52(1), 41-66.

Ryff, C. D. (1989). Happiness Is Everything, or Is It? Explorations on the Meaning of Psychological Well-Being. Journal of pesonality and social psychology, 57(6), 1069-1081.

Ryff, C. D., \& Keyes, C. L. M. (1995). The Structure of Psychological Well-Being Revisited. Journal of pesonality and social psychology, 69(4), 719-727.

Ryff, C. D., Magee, W. J., Kling, K. C., \& Wing, E. H. (1999). Forging Macro-Micro Linkages in the Study of Psychological Well-Being. In C. D. Ryff \& V. W. Marshall (Ed.), The Self and Society in Aging Processes (hal. 247-278). New York: Springer Publishing Company.

Sarstedt, M., Hair, J. F., Cheah, J. H., Becker, J. M., \& Ringle, C. M. (2019). How to specify, estimate, and validate higherorder constructs in PLS-SEM. Australasian Marketing Journal, 27(3), 197-211.

https://doi.org/10.1016/j.ausmj.2019.05.0 03

Sawyer, M. (2019). Organic Beauty and Wellbeing Market 2019.

Schnebelen, S., \& Bruhn, M. (2018). An appraisal framework of the determinants and consequences of brand happiness. Psychology and Marketing, 35(2), 101119. https://doi.org/10.1002/mar.21073

Seligman, M. E. P. (2012). Flourish: A Visionary New Understanding of Happiness and Well-Being (2 ed.). North Sydney: Random House Australia Pty Ltd.

Shaw, E. H., \& Jones, D. G. B. (2005). A history of schools of marketing thought. Marketing Theory, 5(3), 239-281. https://doi.org/10.1177/14705931050548 98

Sheth, J. N., \& Sisodia, R. (2005). Does marketing need reform? In marketing renaissance: Opportunities and imperatives for improving marketing thought, practice, and infrastructure. Journal of Marketing, 69(4), 10-12.

Shultz, C. J., \& Shapiro, S. J. (2014). Constructive Engagement, Macromarketing, and Humanistic Marketing. In R. J. Varey \& M. Pirson (Ed.), Humanism in Business Series: Humanistic Marketing (hal. 176-191). New York: Palgrave Macmillan Ltd.

Sirgy, M. J., \& Lee, D. (2008). Well-being Marketing: An Ethical Business Philosophy for Consumer Goods Firms. Journal of Business Ethics, 77(4), 377403. https://doi.org/10.1007/s10551-0079363-y

Sirgy, M. J., Lee, D., \& Rahtz, D. (2007). Research on Consumer Well-Being ( CWB ): Overview of the Field and Introduction to the Special Issue. Journal of Macromarketing, 27(4), 341-349. https://doi.org/10.1177/02761467073072 12

Smith, N. C., Drumwright, M. E., \& Gentile, M. C. (2010). Insead Marketing Myopia (1). Journal of Public Policy \& Marketing, 29(Spring), 4-11. Diambil dari www.insead.edu

Troebs, C. C., Wagner, T., \& Heidemann, F. (2018). Transformative retail services: Elevating loyalty through customer wellbeing. Journal of Retailing and Consumer Services, 45(September), 198-206. https://doi.org/10.1016/j.jretconser.2018. 09.009

Tung, V. W. S., Chen, P. J., \& Schuckert, M. (2017). Managing customer citizenship behaviour: The moderating roles of employee responsiveness and organizational reassurance. Tourism Management, 59, 23-35. https://doi.org/10.1016/j.tourman.2016.07 .010

Varey, R. J., \& Pirson, M. A. (2014). Humanism 
in Business Series: Humanistic Marketing. London: Palgrave Macmillan Ltd.

Vargo, S. L., \& Lusch, R. F. (2008). Servicedominant logic: Continuing the evolution. Journal of the Academy of Marketing Science, 36(1), 1-10. https://doi.org/10.1007/s11747-0070069-6

Venhoeven, L. A., Bolderdijk, J. W., \& Steg, L. (2013). Explaining the paradox: How proenvironmental behaviour can both thwart and foster well-being. Sustainability (Switzerland), 5(4), 1372-1386. https://doi.org/10.3390/su5041372

Waterman, A. S. (1993). Two Conceptions of Happiness : Contrasts of Personal Expressiveness ( Eudaimonia ) and Hedonic Enjoyment. Journal of pesonality and social psychology, 64(4), 678-691.

Wilkie, W. L., \& Moore, E. S. (1999). Marketing's Contributions to Society. Journal of Marketing, 63, 198-218.

Wilkie, W. L., \& Moore, E. S. (2003). Scholarly Research in Marketing: Exploring the " 4 Eras " of Thought Development, 22(2), 116-146.

Wilkie, W. L., \& Moore, E. S. (2006). Macromarketing as a Pillar of Marketing Thought. Journal of Macromarketing, 26(2), 224-232. https://doi.org/10.1177/02761467062910 67

Wilkie, W. L., \& Moore, E. S. (2007). What does the definition of marketing tell us about ourselves? Journal of Public Policy and Marketing, 26(2), 269-276. https://doi.org/10.1509/jppm.26.2.269

Wilkie, W. L., \& Moore, E. S. (2012). Expanding our understanding of marketing in society. Journal of the Academy of Marketing Science, 40(1), 5373. https://doi.org/10.1007/s11747-0110277-y

Wooliscroft, A. G., \& Wooliscroft, B. (2017). Well-Being and Everyday Ethical Consumption. Journal of Happiness Studies. https://doi.org/10.1007/s10902017-9944-0

Wooliscroft, B. (2014). Rehumanizing
Marketing (and Consumer Behaviour). In R. J. Varey \& M. Pirson (Ed.), Humanism in Business Series: Humanistic Marketing (hal. 53-58). New York: Palgrave Macmillan Ltd. https://doi.org/10.1057/9781137353290

Yi, Y., \& Gong, T. (2008). The effects of customer justice perception and affect on customer citizenship behavior and customer dysfunctional behavior. Industrial Marketing Management, 37(7), 767-783.

https://doi.org/10.1016/j.indmarman.2008 .01 .005

Yi, Y., \& Gong, T. (2009). An integrated model of customer social exchange relationship: The moderating role of customer experience. Service Industries Journal, 29(11), 1513-1528. https://doi.org/10.1080/02642060902793 474

Yi, Y., \& Gong, T. (2013). Customer value cocreation behavior: Scale development and validation. Journal of Business Research, 66(9), 1279-1284. https://doi.org/10.1016/j.jbusres.2012.02. 026

Yi, Y., Gong, T., \& Lee, H. (2013). The Impact of Other Customers on Customer Citizenship Behavior. Psychology and Marketing, 30(4), 341-356. https://doi.org/10.1002/mar

Yi, Y., Nataraajan, R., \& Gong, T. (2011). Customer participation and citizenship behavioral influences on employee performance, satisfaction, commitment, and turnover intention. Journal of Business Research, 64(1), 87-95. https://doi.org/10.1016/j.jbusres.2009.12. 007

Zhao, C., \& Wei, H. (2019). The Highest Hierarchy of Consumption: A Literature Review of Consumer Well-Being. Open Journal of Social Sciences, 07(04), 135149. https://doi.org/10.4236/jss.2019.74012 